\title{
Generalized epilepsy-paroxysmal dyskinesia syndrome
}

INSERM

\section{Source}

INSERM. (1999). Orphanet: an online rare disease and orphan drug data base.

Generalized epilepsy-paroxysmal dyskinesia syndrome. ORPHA:79137

Generalized epilepsy-paroxysmal dyskinesia syndrome is characterised by the association of paroxysmal dyskinesia and generalised epilepsy (usually absence or generalised tonicclonic seizures) in the same individual or family. The prevalence is unknown. Analysis in one of the reported families led to the identification of a causative mutation in the KCNMA1 gene (chromosome 10q22), encoding the alpha subunit of the BK channel. Transmission is autosomal dominant. 